\title{
A case of malignant atrophic papulosis with cranial nerve and peripheral nerve impairment*
}

\author{
Fang Liu ${ }^{1}$ \\ Wenliang Yan ${ }^{1}$
}

\author{
Haibo Liu $^{1}$ \\ Hong Sang ${ }^{1}$
}

Min Zhang ${ }^{1}$

DOI: http:/ / dx.doi.org/10.1590/abd1806-4841.20153490

\begin{abstract}
A bstract: Malignant atrophic papulosisis is a rare, multisystem obliterative vasculopathy of unknown etiology, occasionally involving the cranial nerve. We describe the first case of malignant atrophic papulosisis with cranial nerve and peripheral nerve involvement in China. A 47-year-old woman presented to our hospital with atrophic porcelain white papules over the trunk and extremities, numbness in the right calf, vision decrease and impaired movement of the right eye. She was diagnosed with malignant atrophic papulosisis, based on characteristic symptoms and histopathologic examination. The patient was treated with dipyridamole and aspirin for 9 months, but later died of gastrointestinal hemorrhage. We reviewed currently available case reports on cranial nerve involvement in malignant atrophic papulosisis and emphasized the importance of skin biopsy in diagnosing this disease.
\end{abstract}

Keywords: Cranial nerve injuries; Malignant atrophic papulosis; Peripheral nerve injuries

\section{INTRODUCTION}

Malignant atrophic papulosis (MAP) is a rare, multisystem obliterative vasculopathy of unknown etiology, occasionally involving the cranial nerve. We present a MAP case in a 47-year-old woman with cranial nerve and peripheral nerve involvement.

\section{CASE REPORT}

A 47-year-old woman presented to our clinic with a 6-year history of asymptomatic erythematous papules over the trunk and extremities. The lesions first appeared on her right leg and healed spontaneously, leaving an atrophic residual scar. Similar skin lesions had been appearing gradually and spreading across the whole body surface in the subsequent 5 years. At the age of 46 , the patient experienced a 2-hour episode of visual field constriction in the right eye. Two months later, her right calf was anesthetic and she noticed a painless vision decrease and permanent visual field constriction in her right eye, which prompted her to seek advice.
Cutaneous examination revealed multiple, round and linear, atrophic porcelain white papules of $5-10 \mathrm{~mm}$ in diameter over the trunk and extremities, with some showing an erythematous telangiectatic peripheral halo (Figure 1A). Neurologic examination found hypesthesia and paresis in the right calf. Cranial nerves examination showed that the abducent nerve and optic nerve were impaired, resulting in weakened movement on the right side, visual deterioration, and visual field constriction of the right eye (Figure 1B). Tendon reflexes were normal and Babinski signs were negative.

Histopathology revealed central epidermal atrophy, papillary dermal sclerosis, and perivascular lymphocytic inflammatory cell infiltrates, in addition to vascular thrombosis (Figure 2).

Analytical assessments were normal, including blood cell count, urinalysis, serum chemistry analysis, immunoglobulin profile, myocardial enzymes, CRP, ESR, RF and all plasma autoantibodies. But the fecal occult blood test was positive. Visual evoked potential 

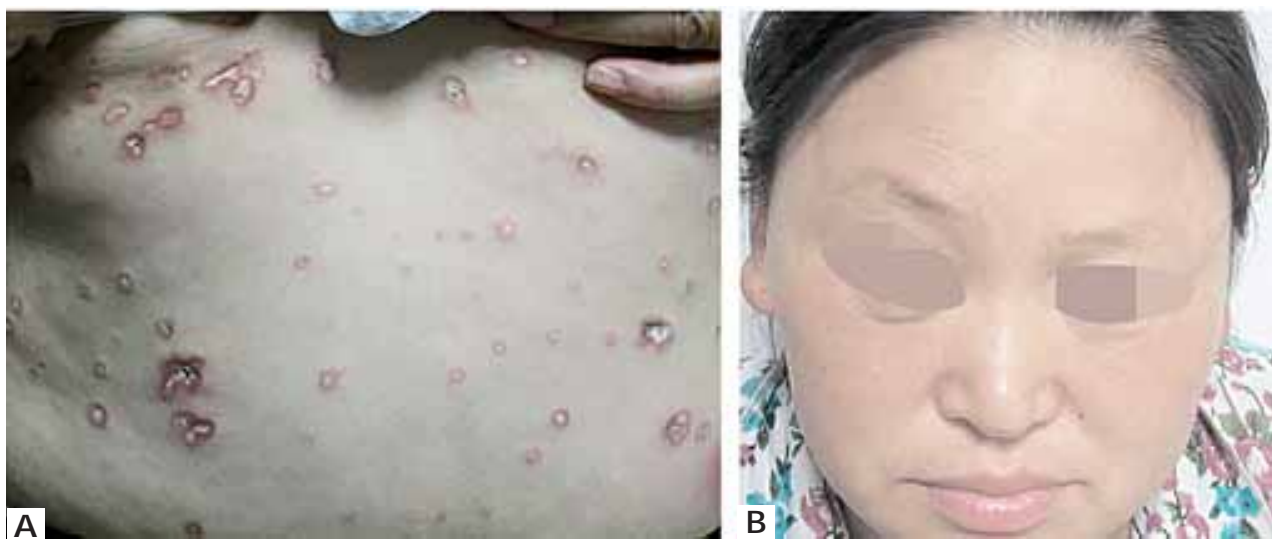

Figure 1: A. Cutaneous examination revealed multiple round and linear atrophic porcelain white papules of $5-10 \mathrm{~mm}$, with some showing an erythematous telangiectatic peripheral halo. B. Cranial nerves examination found impaired movement on the right side, visual deterioration, and visual field constriction of the right eye

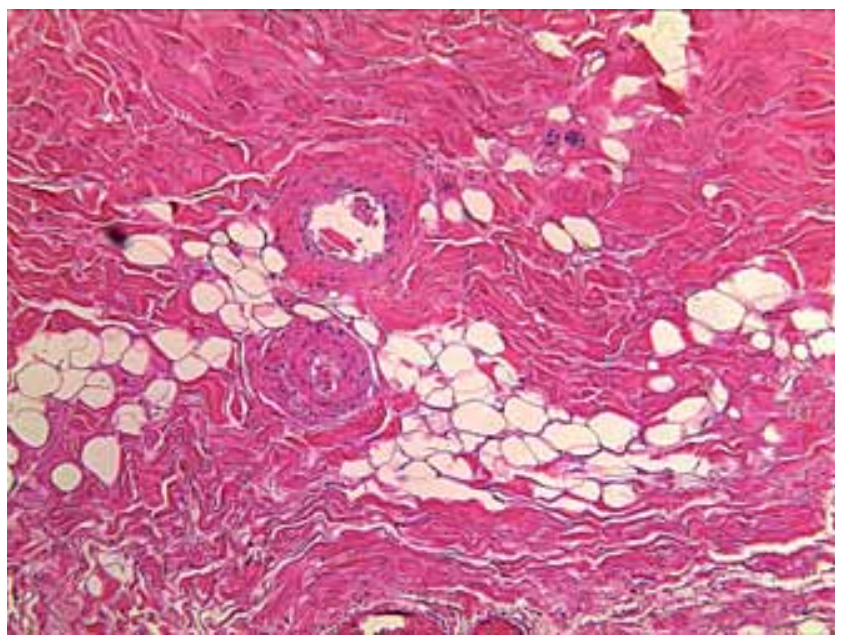

FIgURE 2: Skin biopsies revealed perivascular lymphohistiocytic infiltration. Vascular occlusion was also observed $(\mathrm{HE} \times 400)$

showed the optic nerve was damaged. Ophthalmoscopic findings were normal. Gastroscopy examination uncovered chronic, gastric and duodenal inflammation. Screening colonoscopy demonstrated that the colon was congestive, puffy and erosive, with small, shallow ulcers. Chest computed tomography was normal. No intracerebral damage or venous thrombosis was found, as evidenced by brain magnetic resonance imaging and magnetic resonance angiography. Electromyologram (EMG) showed right quadriceps femoris neurogenic damage.

A diagnosis of MAP was made and the patient was treated with dipyridamole (50mg twice a day) and aspirin (100mg once a day) for 9 months, experiencing no symptoms, skin lesion improvement and no deterioration. The patient was lost to follow-up after 10 months. We later learned that she had died of gastrointestinal hemorrhage a year after presenting to our clinic.

\section{DISAUSSION}

MAP, also known as Degos disease, is a rare, multisystem obliterative vasculopathy of unknown etiology, which frequently affects the skin, gastrointestinal tract and central nervous system. Immunological dysfunction, hyper-coagulation, fibrinolytic disturbances, genetic predisposition and viral or streptococcal infection, may be involved in the pathogenesis of MAP. ${ }^{1-3}$ Drawing on the dialogue 'Degos disease' between Noah Scheinfeld and Stuart Brown, Warren classified MAP into: classical MAP with systemic manifestations, further subclassified into autoimmune MAP, coagulopathy-associated MAP or virally-induced MAP; and benign cutaneous MAP. ${ }^{4}$

Our case is remarkable because of three unusual features. Firstly, physical examination revealed impaired function of cranial nerves, II and VI on the right side, which respectively manifested vision decrease and impaired movement on the right side of the right eye. Her skin lesions were neglected when she visited the department of neurology and ophthalmology. We reviewed currently available case reports on cranial nerve involvement in MAP; our patient was the world's fourth reported case (Chart 1 ) $\cdot^{5-7}$ In addition, some other ophthalmic signs have been reported in $\mathrm{MAP}$, including conjunctival atrophic plaques, telangiectatic vessels, scleral thinning, blepharoptosis and optic atrophy. ${ }^{6,8}$ Secondly, she repeatedly felt numbness in her right calf. EMG showed right quadriceps femoris neurogenic damage, which suggested the patient also had peripheral nerve involvement. Thirdly, although the patient had no clinical symptoms indicating gastrointestinal involvement, the fecal occult blood test was positive and colonoscopy showed that the colon was scattered with superficial ulceration, both of which prompted the diagnosis of intestinal involvement. In ancestral literatures, about $15 \%$ of MAP patients enjoy good health with their lesions limited to the skin. ${ }^{9}$ Once multisystemic disease has developed, death occurs in approximately $50 \%$ of patients within 
ChART 1: Patients' information statistics for cranial nerve involvement in MAP

\begin{tabular}{|c|c|c|c|c|c|c|c|c|c|}
\hline $\begin{array}{l}\text { Year } \\
\text { reported }\end{array}$ & Source & Age & Gender & $\begin{array}{l}\text { Period of } \\
\text { disease } \\
\text { progress } \\
\text { before } \\
\text { cranial } \\
\text { nerve } \\
\text { involved }\end{array}$ & $\begin{array}{l}\text { Cranial nerve } \\
\text { involved }\end{array}$ & $\begin{array}{l}\text { Clinical } \\
\text { Performances } \\
\text { of cranial } \\
\text { nerve involved }\end{array}$ & Therapy & Results & $\begin{array}{l}\text { Refe- } \\
\text { rences }\end{array}$ \\
\hline 2009 & $\begin{array}{l}\text { Birmingham } \\
\text { UK }\end{array}$ & $6 \mathrm{M}$ & Male & 3 weeks & $\begin{array}{l}\text { Oculomotor } \\
\text { nerve } \\
\text { Abducent } \\
\text { nerve }\end{array}$ & $\begin{array}{l}\text { Disconjugate } \\
\text { eye } \\
\text { movements }\end{array}$ & $\begin{array}{l}\text { Analgesics } \\
\text { and antiepileptics }\end{array}$ & $\begin{array}{l}\text { Died of multiple } \\
\text { progressive } \\
\text { cerebral infarc- } \\
\text { tions }\end{array}$ & 5 \\
\hline 2006 & Japan & $58 \mathrm{Y}$ & Female & Initially & Optic nerve & $\begin{array}{l}\text { Loss of vision } \\
\text { in the left eye }\end{array}$ & $\begin{array}{l}\text { Antiplatelet and } \\
\text { anticoagulant }\end{array}$ & $\begin{array}{l}\text { Died of } \\
\text { septic shock }\end{array}$ & 6 \\
\hline 1992 & Japan & $41 Y$ & Male & 3 years & $\begin{array}{l}\text { Facial nerve } \\
\text { Abducent } \\
\text { nerve }\end{array}$ & $\begin{array}{l}\text { Facial } \\
\text { hypesthesia }\end{array}$ & $\begin{array}{l}\text { Heparin, } \\
\text { urokinase, } \\
\text { ticlopidine, } \\
\text { dipyridamole, } \\
\text { and prednisolone }\end{array}$ & $\begin{array}{l}\text { Died of intracra- } \\
\text { nial hemorrhages }\end{array}$ & 7 \\
\hline 2013 & $x$ country & $47 Y$ & Female & 6 years & $\begin{array}{l}\text { Optic nerve } \\
\text { and abducent } \\
\text { nerve }\end{array}$ & $\begin{array}{l}\text { Impaired } \\
\text { movement on } \\
\text { the right side, } \\
\text { visual deteri- } \\
\text { oration, and } \\
\text { visual field } \\
\text { constriction of } \\
\text { the right eye }\end{array}$ & $\begin{array}{l}\text { Dipyridamole, } \\
\text { aspirin }\end{array}$ & $\begin{array}{l}\text { Died of gas- } \\
\text { trointestinal } \\
\text { hemorrhage }\end{array}$ & $\begin{array}{l}\text { Present } \\
\text { case }\end{array}$ \\
\hline
\end{tabular}

one to two years. The most common causes of death are sepsis from peritonitis, CNS bleeding, and pleural or pericardial. ${ }^{4}$

There is no specific therapy for MAP. Some cases respond well to antiplatelets treatment. Darwich has reported a MAP case in which skin lesions improved significantly after treatment with chloroquine, aspirin and prednisone. ${ }^{2}$ Magro has investigated four
MAP cases and found prominent vascular C5b-9 in the skin, gastrointestinal tract and brain..$^{10}$ In all cases, they also found evidence of high interferon- $\alpha$ (IFN- $\alpha)$ expression. They proposed that $\mathrm{C} 5$ or IFN- $\alpha$ may emerge as potential candidate targets.

\section{REFERENCES}

1. Hohwy T, Jensen MG, Tøttrup A, Steiniche T, Fogh K. A fatal case of malignant atrophic papulosis (Degos' disease) in a man with factor $\mathrm{V}$ Leinden mutation and lupus anticoagulant. Acta Derm Venereol. 2006:86:245-7.

2. Darwich E, Guilabert A, Mascaró JM Jr, Malvehy J, Puig S, Fernandez-Figueras $M$, et al. Dermoscopic description of a patient with thrombocythemia and factor V Leiden mutation-associated Degos' disease. Int J Dermatol. 2011;50:604-6.

3. Pati S, Muley SA, Grill MF, Coons S, Walker R. Post-streptococcal vasculopathy with evolution to Degos' disease. J Neurol Sci. 2011;300:157-9.

4. Heymann WR. Degos disease: considerations for reclassification. J Am Acad Dermatol. 2009;61:505-6.

5. Moss C, Wassmer E, Debelle G, Hackett S, Goodyear H, Malcomson R, et al. Degos disease: a new simulator of non-accidental injury. Dev Med Child Neurol. 2009;51:647-50.

6. Matsuura F, Makino K, Fukushima T, Matsubara N, Shibuya M, Higuchi T, et al. Optic nerve and spinal cord manifestations of malignant atrophic papulosis (Degos disease). J Neurol Neurosurg Psychiatry. 2006;77:260-2.

7. Aizawa H, Takase Y, Inoue K, Murayama S, Mannen T. An autopsy case of Degos disease with neurological symptoms--neuropathological observations and increased platelet aggregation. Rinsho Shinkeigaku. 1992;32:23-9.
8. Gutiérrez-Pascual M, Hernández-Martín A, Colmenero I, García-Peñas JJ, LópezPino MA, Torrelo A. Malignant atrophic papulosis: a case report with severe visual and neurological impairment. Pediatr Dermatol. 2011;28:302-5.

9. Wilson J, Walling HW, Stone MS. Benign cutaneous Degos disease in a 16-yearold girl. Pediatr Dermatol. 2007;24:18-24.

10. Magro CM, Poe JC, Kim C, Shapiro L, Nuovo G, Crow MK, Crow YJ, et al. Degos disease: a C5b-9/interferon-alpha-mediated endotheliopathy syndrome. Am J Clin Pathol. 2011;135:599-610.

M AILING ADDRESS:
H ong Sang
Zhongshan East Road
N anjing City, Jiangsu, China
E-mail: sanghong@nju.edu.cn

M AILING ADDRESS:

$H$ ong Sang

Zhongshan East Road

E-mail: sanghong@nju.edu.cn

H ow to cite this article: Liu F, Liu HB, Zhang M, Yan WL, Sang H. A case of malignant atrophic papulosis with cranial nerve and peripheral nerve impairment. An Bras Dermatol. 2015;90(3 Suppl 1):S19-21. 